\title{
Kebijakan Telemudik Bentuk Perlindungan Negara Pada Masyarakat Menuju New Normal Ditengah Pendemi Corona
}

\author{
Amalia Syauket ${ }^{1, *}$, Bambang Karsono ${ }^{1}$, Dwi Atmoko ${ }^{1}$ \\ ${ }^{1}$ Fakultas Hukum; Universitas Bhayangkara Jakarta Raya; Jln.Perjuangan 081,Marga \\ Mulya,Bekasi Utara,02188955882/+6221889558871; e-mail: \\ amalia.syuaket@dsn.ubharajaya.ac.id, bambang.karsono@dsn.ubharajaya.ac.id, \\ dwi.atmoko@dsn.ubharajaya.ac.id \\ * Korespondensi: e-mail: amalia.syuaket@dsn.ubharajaya.ac.id \\ Submitted: 03/08/2021; Revised: 18/11/2021; Accepted: 22/11/2021; Published: 31/01/2022
}

\begin{abstract}
The number of people who have died from COVID-19 has also continued to increase, as has the number of people infected with the Corona virus (Covid-19). Until May 2021, which coincides with the Eid al-Fitr $1442 \mathrm{H}$, which is the custom of the people of Jakarta, to go home to stay in touch with family in the area. At that time, Jakarta was still in the red zone due to the spike in the spread of Covid-19 cases. The state, in this case the Government, must be present to protect its people, both those infected with COVID-19 and so that they are not infected with Covid-19. This protection is in the form of the issuance of a regulation in the form of a Covid-19 Handling Task Force Circular Number 13 of 2021 concerning the Elimination of Homecoming for Eid Al-Fitri in 1442 Hijri and efforts to control the spread of Covid-19 during the holy month of Ramadan 1442 Hijri to change the ignorance of the people towards the Covid-19 pandemic. This study uses a qualitative approach by prioritizing secondary data, to find out the background of the issuance of the telemudik policy. The conclusion drawn from this literature research is that the background behind the birth of the telemudik policy is the ignorance of the community towards the covid pandemic itself. The right solution for carrying out homecoming during the Covid-19 pandemic is telemudik not to reduce the essence of friendship and sharing and prepare the community for the New Normal. in the midst of the Corona pandemic.
\end{abstract}

Keywords: Public Ignorance, State Protection, Telemudik

\begin{abstract}
Abstrak
Jumlah masyarakat yang meninggal dunia akibat covid-19 juga terus meningkat begitu pula dengan jumlah masyarakat yang terinfeksi virus corona (Covid-19). Sampai dengan bulan Mei 2021 bertepatan menjelang hari raya Idul Fitri $1442 \mathrm{H}$, yang secara adat kebiasaan masyarakat Jakarta, melakukan mudik untuk bersilahturahmi dengan keluarga di daerah. Pada saat itu, Jakarta masih dalam zona merah karena lonjakan sebaran kasus Covid-19. Negara dalam hal ini Pemerintah harus hadir melindungi masyarakatnya baik yang terinfeksi covid-19 maupun agar tidak terinfeksi Covid-19. Perlindungan tersebut berupa diterbitkannya Regulasi berupa Surat Edaran Satuan Tugas Penanganan Covid-19 nomor 13 tahun 2021 tentang Peniadaan Mudik Hari raya idul fitri tahun 1442 Hijriah dan upaya pengendalian penyebaran covid-19 selama bulan suci Ramadhan 1442 Hijriah untuk mengubah perilaku ignorance masyarakat terhadap pandemic Covid-19. Penelitian ini menggunakan pendekatan kualitatif dengan mengutamakan data sekunder, untuk mengetahui apa latar belakang terbitnya kebijakan telemudik tersebut. Kesimpulan yang ditarik dari penelitian kepustakaan ini bahwa yang melatarbelakangi lahirnya kebijakan telemudik adalah perilaku ignorance masyarakat terhadap pandemic covid itu sendiri Solusi yang tepat untuk melaksanakan mudik pada masa Pandemi
\end{abstract}


Covid-19 adalah dengan telemudik untuk tidak mengurangi esensi bersilahturahmi dan berbagi dan mempersiapkan masyarakat menuju New Normal ditengah Pendemi Corona.

Kata kunci: Ignorance Masyarakat, Perlindungan Negara, Telemudik

\section{Pendahuluan}

Gubernur DKI Jakarta Anies Baswedan memberikan pernyataan bahwa pemudik yang meninggalkan Jakarta, belum tentu dapat memasuki kembali wilayah Jakarta kembali. Pernyataan Gubernur tersebut menindaklanjuti aturan pemerintah yang melarang mudik sehubungan dengan upaya pencegahan persebaran Covid-19. Kebijakan ini dapat dipahami menginagt aktivitas mudik dapat berdampak pada semakin menyebarnya Covid-19 dan kini Indonesia, khususnya Jakarta belum memasuki grafik puncak Covid-19 (Christiawan, 2020).

Artinya, sejauh ini kebijakan larangan mudik oleh Pemerintah dapat dipahami sebagai langkah untuk melindungi masyarakat dari ancaman Covid-19 dengan harapan agar pandemic Covid-19 segera berakhir dan segera dapat dilakukan kegiatan pemulihan ekonomi yang kini sedang lesu. Momen mudik tahun 2021 yang merupakan pemenuhan kebutuhan spiritual yang menjadi esensi mudik tetap dapat dilakukan dengan berbagai manfaat koneksi internet dan kecerdasan buatan yang memungkinkan konektivitas tanpa batas. Dengan demikian telemudik merupakan mudik secara virtual.

Teori yang relevan dengan penelitian ini yang menjadi pisau analisa dan pembahasan dalam artikel ini berangkat dari pengertian Telemudik dari Biriyani tahun 2015 dan teori tentang perilaku ignorance dari Hertwign R \& Engel C tahun 2016 untuk menjawab atas pertanyaan penelitian apa yang melatarbelakangi terbitnya kebijakan telemudik. Sedangkan teori State Paternalistic dari Desere (2000) digunakan untuk menjelaskan hubungan antara Negara dengan masyarakat pada masa terjadinya wabah seperti pandemic covid-19.

\section{Metode Penelitian}

Tema pada artikel penelitian ini masuk dalam rumpun ilmu pemerintahan, karena terkait dengan berjalannya roda fungsi-fungsi pemerintahan berupa pengaturan. Metode penelitian ini menggunakan pendekatan metode kualitatif dengan pendekatan fenomenologi yang meneropong fenomena telemudik pada Idul Fitri 1442 Hijriah tahun 2021 pada saar adanya pandemi covid-19. Dengan menggunakan sumber utama berupa data sekunder atau kajian literatur dimana pencarian literatur dilakukan melalui di Google Scholar dan Google Engine dengan bahasa Indonesia menggunakan kata kunci tertentu dan periode publikasi 2020 sampai dengan tahun 2021. Penelitian ini berawal dari keingin tahuan apa yang dimaksud dengan Telemudik. Sehingga dirumuskan dalam masalah penelitian apa yang melatarbelakangi lahirnya kebijakan telemudik tersebut?. Pembahasan dan Analisa berdasarkan data sekunder, kajian literature terkini, disampaikan secara naratif. 


\section{Hasil dan Pembahasan}

Isu mudik sudah terjadi pada akhir Maret tahun 2021 didorong pemberitaan tentang tingginya arus lalu perpindahan manusia keluar Jakarta. Pada saat bersamaan Jakarta dalam zona merah yaitu wilayah yang telah sangat parah atau tidak terkendali penyebaran dan penularannya. @najwashihab menarasikan Jakarta adalah pusat wabah, stop arus keluar warga dari DKI Jakarta. Menghadapi berbagai pemberitaan tersebut @ganjarpranowo dan @ridwankamil narasikan mudik sebagai potensi sebar corona. @tirtolD: mudik dapat memperparah penyebaran covid-19. @CNNIndonesia ganjar, RK, dan anies sepakat larang warga pulang kampung.

Jumlah masyarakat yang terinfeksi virus corona (Covid-19) dan jumlah yang meninggal dunia akibat Covid-19 terus meningkat. Kini faktanya motality rate atau angka kematian dari masyarakat yang terkena covid-19 di Indonesia merupakan salah satu yang tertinggi di dunia. Semua pihak harus sadar bahwa Covid-19 merupakan bencana yang bukan salah siapapun.. mengingat hal tersebut, sikap saling menyalahkan justru akan berkontraproduktif dengan semangat kebersamaan dalam melawan Covid-19, sebagaimana sudah disampaikan oleh WHO bahwa Covid-19 sudah dikategorikan sebagai pandemic yang merupakan ancaman bagi peradaban manusia (Christiawan, 2020).

Akibat dari penyebaran Covid-19 yang begitu cepat, menyebabkan Indonesia mengalami kepanikan dan kesulitan dalam menghadapinya. Kepanikan ini terjadi karena Covid19 adalah penyakit baru namun penyebarannya begitu cepat (Panjaitan, 2020). Data dari Menteri Kordinator Kemaritiman \& Investasi selaku Kordinator PPKM Jawa-Bali menunjukan trend yang mengkawatirkan karena peningkatan kasus setiap hari nya. Pada gambar 1 menampilkan grafik fenomena yang terjadi.

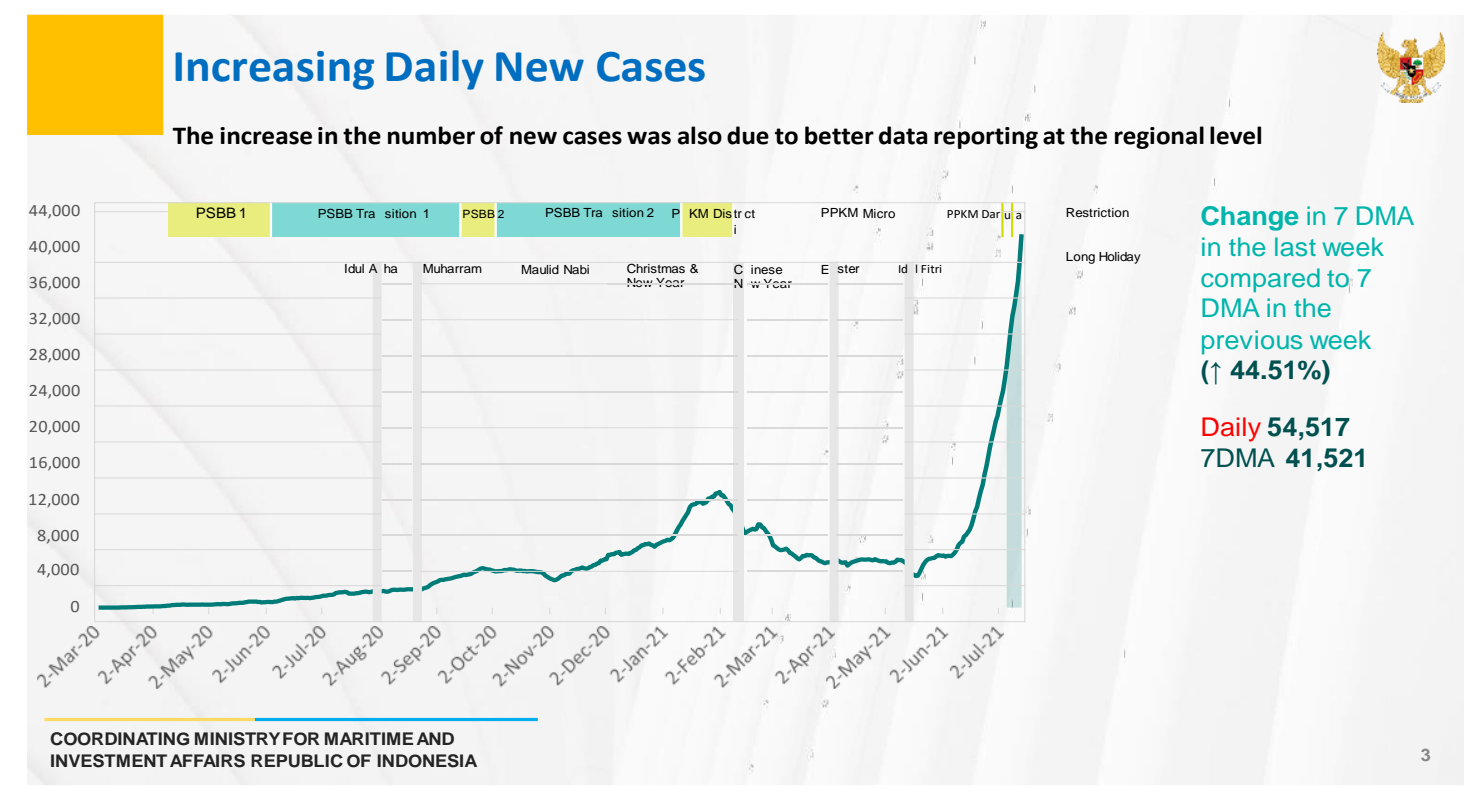

Sumber: Coordinating Ministry for Maritime and Invesment Affairs (Biswas, 2021)

Gambar 1. Grafik Peningkatan Kasus Covid-19 
Pemerintah di masa pandemic covid-19 telah menerbitkan aturan yang melarang masyarakat untuk melaksanakan mudik sehubungan dengan liburan lebaran tahun 2021. Pelarangan tersebut sehubungan dengan strategi pemerintah dalam penanganan covid-19 yakni terkait social and physical distancing . karena mudik pada umumnya dimanfaatkan umat muslim untuk merayakan lebaran bersama keluarga dan dimanfaatkan oleh masyarakat untuk bertemu. Lebih lanjut Majid (1997) menjelaskan bahwa esensi mudik adalah momentum kebersamaan antaranggota keluarga yang mungkin pada hari biasanya tidak dapat bertemu. Namun, dalam kondisi adanya pandemi covid-19 membuat pemerintah harus melakukan pembatasan pada aktivitas masyarakat termasuk dalam hal ini aktivitas mudik secara phisik, dalam artian adanya pergerakan masyarakat dari satu tempat, dari Jakarta menuju berbagai daerah.

Tujuan dari social and physical distencing atau jaga jarak pada kondisi pandemi covid19 antara lain a) Menghindari resiko terkena droplet covid-19, karena droplet dari orang berbicara, berbisik, batuk, dan bersin dapat menjadi sumber penularan covid-19 dengan melakukan jaga jarak, minimal jaga jarak yang dirsarankan adalah 2 meter; b) Melindungi anggota keluarga, sementara tidak perlu melakukan sentuhan phisik saat bertemu seperti bersalaman, cium pipi atau berpelukan; c) Memutus rantai penularan covid-19 salah satunya dengan menghindari tempat umum, pusat keramaian, social and physical distancing atau jaga jarak ini merupakan tindakan non medis yang bisa dilakukan oleh masyarakat dengan membatasi kontak sosial dengan banyak orang.

Maksud dari pelarangan mudik secara phisik di saat pandemic covid-19 adalah untuk melindungi segenap masyarakat dari virus covid-19 yang mematikan serta guna mengendalikan area terdampak penyebaran covid-19. Jadi pada hakekatnya pembatasan tersebut dimaksudkan untuk memberikan perlindungan bagi masyarakat, bukan untuk mengurangi hak dari masyarakat untuk merayakan hari besar beragama. Dengan kata lain, aturan pembatasan mudik secara phisik yang diberlakukan pemerintah mengacu pada tujuan yang baik yakni melindungi masyarakat dan orang terdekat dari ancaman virus Covid-19.

\subsection{Telemudik sebagai suatu Pilihan Kebijakan}

Mudik merupakan salah satu tradisi yang selalu dilakukan oleh hampir seluruh masyarakat Indonesia sebagai simbol perayaan menyambut datangnya hari raya idul fitri bersama keluarga tercinta di kampung halaman.

Tradisi mudik Lebaran sebenarnya mulai muncul pada tahun 1970-an. Saat itu Jakarta masih merupakan satu-satunya kota besar di Indonesia. Banyak orang dari berbagai daerah mengadu nasib ke kota Jakarta untuk mencari pekerjaan dan penghidupan yang lebih baik. Mereka ada yang bekerja di kantor-kantor pemerintah, kantor-kantor swasta, bekerja di pabrik dan berbagai industri, bahkan ada juga sebagai pekerja informal di berbagai bidang usaha, yang juga tumbuh sangat pesat saat itu.Kian tahun, jumlah yang mudik lebaran semakin banyak dan menyebar ke berbagai kota dengan jumlah pemudik yang kian meningkat jumlahnya. Bahkan cerita tentang mudik di masa libur Lebaran di Indonesia ini telah menjadi fenomena migrasi manusia dari kota satu ke kota lainnya dalam jumlah yang sangat banyak, 
mencapai jutaan manusia, dan sangat fenomenal.Belakangan, fenomena mudik lebaran tidak hanya dilakukan oleh masyarakat muslim saja tetapi sudah menjadi tradisi tahunan yang tidak dapat dipisahkan dengan komunitas masyarakat Indonesia.

Pandemi COVID-19 mengakibatkan berbagai kegiatan tidak dapat dilakukan secara normal seperti sebelumnya, termasuk tradisi mudik pada bulan suci Ramadan hingga menjelang lebaran yang terpaksa turut dilarang untuk mengurangi serta memutus rantai penyebaran virus corona.

Berat jika melarang masyarakat Indonesia untuk tidak mudik. Mudik telah menjadi budaya dan tradisi yang begitu kental bagi masyarakat, semua kalangan.Namun demikian, kebijakan Tidak mudik lebaran menjadi opsi Pemerintah untuk menekan mobilitas dalam rangka mengurangi penularan dan penyebaran Virus Covid-19. Kebijakan "Tidak Mudik Lebaran 2020" jadi salah satu alternatif yang diambil jika status darurat dari wabah virus corona masih diberlakukan. Sejauh ini, status darurat berlaku hingga 29 Mei 2019 berdasarkan keputusan Badan Nasional Penanggulangan Bencana (BNPB). Sementara untuk Lebaran Idul Fitri 1442 Hijriah diprediksi akan jatuh pada tanggal 23-24 Mei 2020. Penggunaan teknologi berbasis aplikasi di gawai menjadi solusi. Masyarakat di era revolusi industri 4.0 tidak bisa lepas dari teknologi. Pengaruh teknologi komunikasi sangat berdampak signifikan dalam praktik keseharian, karena nyaris seluruh aktivitas masyarakat mendapatkan bantuan teknologi.

Masyarakat hanya perlu untuk sementara waktu mengubah cara melakukan mudik, yang biasanya sesuai tradisi dan budaya adalah mudik secara phisik, kini dalam kondisi Pandemi Covid-19 masyarakat harus menggunakan teknologi dan fasilitas yang ada guna melakukan telemudik, dengan esensi meskipun tidak berada pada satu tempat yang sama namun tidak mengurangi semangat berbagi dan tidak mengurangi esensi spritualitas perjumpaan pada tradisi mudik (Christiawan, 2020). Alasan dari perubahan ini adalah mencegah penyebaran virus corona Covid-19. Mudik ke kampung halaman demi berlebaran bisa berefek meningkatkan pasien positif corona di Indonesia. Pasiennya adalah sanak saudara di kampung halaman. Bisa saja virus ini terbawa oleh mereka yang mudik.

Menurut Biriyani (2015), telemudik sudah banyak dipergunakan oleh banyak masyarakat, khususnya dalam kondisi pembatasan akibat perang, pandemic, maupun factor alam lainnya. Telemudik merupakan pilihan yang terbaik dan paling ideal bagi masyarakat untuk menghindarkan masyarakat dari ancaman pandemic covid-19. Telemudik atau sering disebut juga dengan Lebaran secara virtual adalah bersilaturahmi dengan keluarga dalam suasana Lebaran dan Idul Fitri dengan menggunakan berbagai aplikasi jaringan internet yang menyediakan video call gratis. Misalnya, Zoom, WhatsApp, Google Duo dan lain sebagainya (Roy, 2020). Ketua Gugus Tugas Percepatan Penanganan COVID-19, Doni Monardo menyatakan "Program \#MudikOnline dengan TikTok merupakan salah satu upaya dalam memberikan solusi yang kreatif, sehingga masyarakat tetap bisa terhubung dengan keluarganya di kampung halamannya dan merayakan hari raya Idul Fitri, meskipun tetap 
melakukanphysicaldistancing,(CNNIndonesia). Dengan kata lain, lebaran kali ini momen Temu kangen tersambung melalui gadget.

Keuntungan lain dari telemudik, masyarakat tidak perlu mengeluarkan biaya untuk melakukan perjalanan mudik. Telemudik juga mencegah agar masyarakat tidak bersifat konsumtif saat musim liburan tiba, memutus rantai penularan Covid-19. Artinya telemudik tidak mengurangi esensi unsure berbagi kebaikan pada kegiatan mudik itu sendiri. Tantangannya bagi masyarakat adalah menikmati perubahan cara mudik dari cara-cara konvensional menjadi telemudik.

Masyarakat menyambut baik kebijakan Larangan Mudik dan menggantikannya dengan mudik secara virtual atau telemudik dengan memberikan berbagai tanggapan antara lain seperti yang tampak pada Tagar berupa Narasi imbauan, ajakan, dan dukungan dari berbagai pihak dan warganet untuk tidak mudik, ramai digaungkan dengan semua tagar yang diantaranya \#LebihBaikDiRumahAja, \#AyoBijakCegahCorona, \#TundaMudikCekalCorona, \#dirumahaja, dan lain-lainnya.Pembahasan mengenai sejumlah kepala daerah yang meminta warga perantau tidak mudik selama pandemi virus Corona, terutama imbauan Gubernur Jawa Barat Ridwan Kamil kepada warga Jabar yang tinggal/merantau atau bekerja di Jakarta untuk tidak pulang kampung atau mudik demi mencegah penularan Covid-19, ramai diunggah di Youtube. Ridwan Kamil jadi aktor utama yang banyak disebut terkait pernyataannya yang melarang mudik. Diikuti Gubernur Jawa Tengah, Ganjar Pranowo yang memohon agar jangan mudik, untuk memutus penyebaran virus Corona. (https://sinta.ristekbrin.go.id/).

Memang sudah sepatutnya hari kemenangan dirayakan bersama orang-orang tersayang. Namun kali ini, kita semua masih terjebak dalam kondisi pandemi. Kita semua masih harus sama-sama berusaha untuk menekan angka penularan Covid-19. Tidak mudik bukan berarti tidak bisa merayakan Idulfitri dengan suka cita. Lewat Telemudik atau mudik virtual, rindu kampung halaman bisa terobati tanpa harus korbankan orang terkasih.

\subsection{Perilaku ignorance Latar belakang terbitnya Kebijakan Telemudik}

Kebijakan telemudik ini berangkat dari pertanyaan "Mengapa masih banyak orang yang belum mengubah kebiasaan atau perilakunya dalam menerapkan protokol kesehatan?" padahal perubahan perilaku merupakan satu faktor kunci terbesar kesuksesan memerangi penyebaran Covid-19. Sebagian perilaku dan kebiasaan masyarakat memang sudah berubah, seperti memakai masker, membawa hand sanitizer, mencuci tangan, menggunakan face shield, dan sebagainya. Kebiasaan baru tersebut sering terlihat hanya terjadi di kota-kota besar.

Menurut Indradie (2020) sejak awal pandemi sampai sekarang, muncul tiga jenis golongan di masyarakat. Golongan pertama, mereka yang punya pengetahuan tentang Covid19, tetapi jarang turun ke lapangan. Golongan Kedua, golongan yang paham Covid-19, punya pengetahuan, dan aktif turun ke lapangan serta melibatkan diri. Golongan ketiga, mereka yang abai, tidak peduli, dan ignorance alias kurang informasi dan pengetahun. Yang paling banyak adalah golongan pertama dan ketiga. 
Dari fakta tersebut menunjukan bahwa dalam bencana, musuh terbesar manusia adalah manusia itu sendiri. Perilaku egois dan ignorance akan dapat membunuh manusia lainnya. Perilaku ignorance berupa tidak disiplin serta mengabaikan terhadap larangan sehubungan dengan penanganan Covid-19 akan menjadi sumber penularan Covid-19. Akibatnya jumlah masyarakat yang terinfeksi Covid-19 akan terus bertambah. Misalnya jika masyarakat ignorance seperti tidak disiplin terhadap kebijakan social distancing maupun physical distancing, penularan akan terjadi dengan cepat dan manusia yang satu akan menjadi carrier bagi manusia yang lain (Christiawan, 2020). Perilaku ignorance merupakan bagian dari penyebaran pandemic covid-19.

Kebijakan Telemudik dilatarbelakangi masih banyaknya masyarakat yang berperilaku ignorance dalam menghadapi pandemic covid-19. Mereka sengaja tidak peduli tentang Covid19, kurangnya sense of community dari masyarakat. Masyarakat cenderung memandang persoalan penularan COVID-19 ini adalah masalah personal/ individu daripada sebagai persoalan komunitas/ masyarakat (Rohmah, 2020). Upaya yang paling efektif untuk melawan pandemic covid-19 dengan menerapkan upaya terbaik bagi masing-masing masyarakat tidak terbatas pemerintah saja. maknanya masyarakat saling menjadi penolong bagi masyarakat lainnya maupun juga bagi pemerintah. Sehingga hubungan antara masyarakat dengan pemerintah adalah hubungan saling tolong menolong dan saling melindungi dari penyebaran pandemic covid-19.

Pada masa ketidak pastian seperti saat ini, pemerintah perlu membentuk perilaku masyarakat sehingga terwujud perilaku upaya terbaik bagi sesama masyarakat. Dengan menerbitkan Kebijakan berupa Surat Edaran (SE) Satuan Tugas Penanganan Covid-19 Nomor 13 Tahun 2021 tentang Peniadaan Mudik Hari Raya Idul Fitri Tahun 1442 Hijriah dan Upaya Pengendalian Penyebaran Covid-19 Selama Bulan Suci Ramadhan 1442 Hijiah (Presiden RI, 2021), Pemerintah berupaya membentuk perilaku masyarakat membangun solidaritas melawan Covid-19. Karena dalam penanganan covid-19 semakin masyarakat egois pada kepentingannya dan semakin tinggi ignorance masyarakat, maka sesungguhnya akan memperpanjang penderitaan masyarakat lainnya dari seluruh aspek kehidupan.

\subsection{Kebijakan Telemudik bentuk Perlindungan Negara pada Masyarakat}

Kondisi bencana dan ketidakpastian maka hubungan antara Negara dalam hal ini pemerintah dengan warga negaranya menjadi suatu hubungan yang bersifat state paternalistic. Artinya peran Negara sangat dominan dalam menentukan kelangsungan kehidupan warga negaranya (Desere, 2000). Maknanya dalam kondisi pandemic covid-19 seperti ini, pemerintah memegang peranan yang besar dalam menentukan perlindungan warganegara, baik yang telah terinfeksi covid-19 maupun agar tidak terinfeksi covid-19 (Christiawan, 2020).

Konsep state paternalistic, Negara harus memberikan perlindungan kepada warganegaranya yang paling lemah dan kurang beruntung (Desere, 2000). Ukuran humanistic dalam penanganan covid-19 yang harus dipergunakan oleh Pemerintah adalah memberi 
prioritas pada masyarakat yang paling kurang beruntung. Definisi kurang beruntung salah satunya menurut tingkat kesehatan.

Secara umum, New normal ini dalam arti kehidupan baru dan kebiasaan hidup baru yang harus kita lakukan di masa pandemi Covid-19 ini untuk mengikuti kebiasaan baru atau hidup baru kita perlu mematuhi mematuhi protokol kesehatan yang sudah di anjurkan, bertujuan untuk mempercepat penanganan COVID-19 dalam aspek kesehatan dan sosial-ekonomi.

Indikator New Normal Saat Pandemi Corona menurut Menteri Perencanaan Pembangunan Nasional (PPN)/Kepala Badan Perencanaan Pembangunan Nasional (Bappenas), Suharso Monoarfa, antara lain a) Tidak menambah penularan atau memperluas penularan atau semaksimalnya mengurangi penularan; b) Menggunakan indikator sistem kesehatan yakni seberapa tinggi adaptasi dan kapasitas dari sistem kesehatan bisa merespons untuk pelayanan covid-19; c) Surveilans yakni cara menguji seseorang atau sekelompok kerumunan apakah dia berpotensi memiliki covid-19 atau tidak sehingga dilakukan tes massif.

Covid-19 memang benar-benar luar biasa. Covid-19 adalah penyakit yang disebabkan oleh virus corona, sebuah makhluk sangat kecil berukuran sekitar 125 nanometer namun bisa menyebabkan kematian. Covid-19 ditandai dengan munculnya gejala batuk pilek, flu, demam, gangguan pernapasan, namun ada juga yang tidak nampak/muncul gejalanya, dan dalam kondisi parah bisa menyebabkan gagal napas dan berakhir pada kematian. Penularannya melalui droplets atau percikan batuk atau bersin. Virus dapat berpindah secara langsung melalui percikan batuk atau bersin dan napas orang yang terinfeksi yang kemudian terhirup orang sehat. Virus juga dapat menyebar secara tidak langsung melalui benda-benda yang tercemar virus akibat percikan atau sentuhan tangan yang tercemar virus. Virus bisa tertinggal di permukaan benda-benda dan hidup selama beberapa jam hingga beberapa hari, namun cairan disinfektan dapat membunuhnya.

Untuk melawan virus corona, hal utama yang perlu kita lakukan adalah melakukan tindakan pencegahan seperti: sering cuci tangan pakai sabun, menerapkan etika pakai masker, meningkatkan daya tahan tubuh, menjaga jarak dan hindari kerumunan, seperti tampak pada gambar 2.

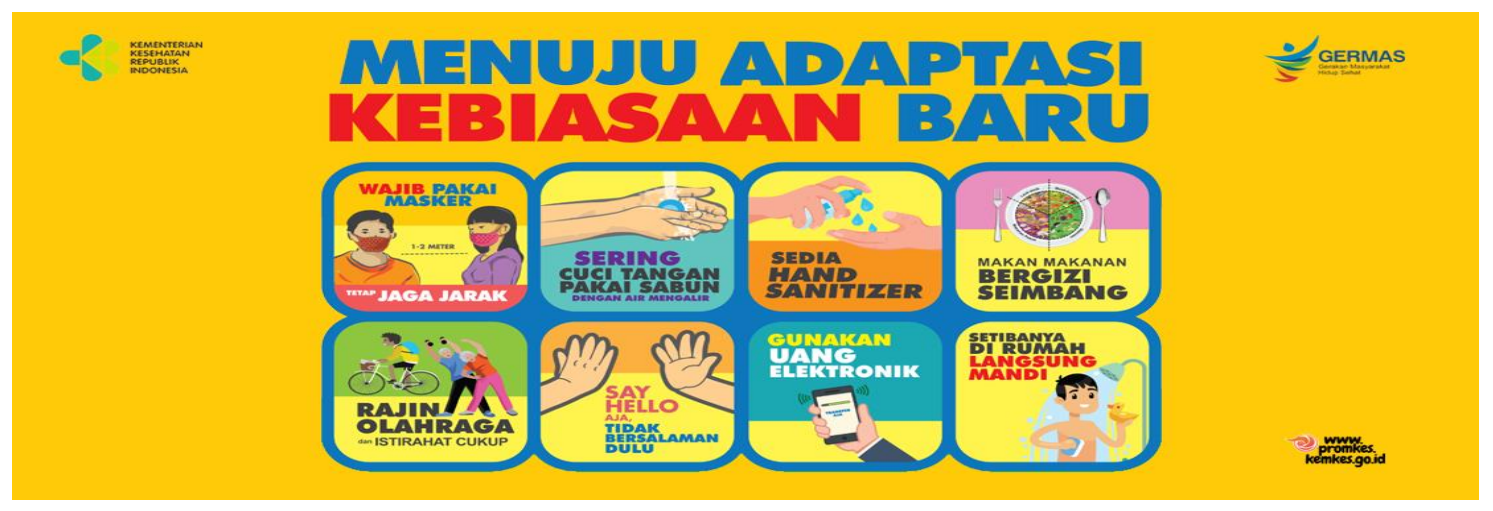

Sumber: https://www.google.com/search?q=apa+arti+new+normal+masa+pandemi+corona

Gambar 2. Arti New Normal dimasa pandemi corona 
Bentuk Perlindungan Negara kepada warganegaranya berupa penyediaan Kualitas layanan internet tetap bagus dan mencukupi secara kapasitas, sehingga mudik virtual di mana masyarakat bisa video call, memanfaatkan telekonferensi dengan keluarga bisa tercukupi.

Presiden RI Joko Widodo dalam pidato resminya di Istana Merdeka (15 Mei 2020) menyatakan bahwa: "Kehidupan Kita sudah pasti berubah untuk mengatasi risiko wabah ini. Itu keniscayaan. Itulah yang oleh banyak orang disebut sebagai New Normal atau tatanan kehidupan baru.

Pada masa pandemi masyarakat Indonesia diharuskan hidup dengan tatanan hidup baru, yang dapat 'berdamai' dengan COVID-19. Adapun yang dimaksud dengan New Normal adalah suatu tindakan atau perilaku yang dilakukan oleh masyarakat dan semua institusi yang ada di wilayah tersebut untuk melakukan pola harian atau pola kerja atau pola hidup baru yang berbeda dengan sebelumnya. Bila hal ini tidak dilakukan, akan terjadi risiko penularan.Tujuan dari New Normal adalah agar masyarakat tetap produktif dan aman dari Covid-19 di masa pandemi.

\section{Kesimpulan}

Terbitnya Kebijakan berupa Surat Edaran Satuan Tugas Penanganan Covid-19 nomor 13 tahun 2021 tentang: Peniadaan Mudik Hari Raya Idul Fitri tahun 1442 Hijiriah dan Upaya Pengendalian Penyebaran Covid-19 selama Bulan Suci Ramadhan 1442 Hijriah dilatar belakangi dengan adanya perilaku ignorance masyarakat terhadap Pandemi Covid-19 itu sendiri. Solusi yang tepat dengan menggunakan telemudik untuk tidak mengurangi esensi bersilahturahmi dan berbagi, dalam rangka mempersiapkan masyarakat menuju New Normal ditengah Pendemi Corona.New normal dianggap sebagai jalan keluar terbaik di tengah pandemi virus Corona. New normal berarti hidup dan menjalani aktivitas, pekerjaan, dan interaksi dengan orang lain dengan cara yang baru. Hubungan antara Negara dengan warganegaranya menjadi suatu hubungan yang sifatnya state paternalistic, artinya peran Negara sangat besar dalam menentukan kelangsungan kehidupan warganegaranya. Maknanya, dalam masa Pandemi Covid-19 seperti saat ini, Pemerintah memegang peranan yang sangat besar untuk melindungi warganegaranya baik yang telah terinfeksi Covid-19 maupun agar tidak terinfeksi Covid-19.

\section{Daftar Pustaka}

Biriyani. (2015). Developing Countries Culture and Civilization. Dallas: Dallas Stinson Publishing.

Biswas, S. (2021, May 26). Covid-19: Has India â $€^{\mathrm{TM}} \mathrm{s}$ deadly second wave peaked? BBC News. Retrieved from https://www.bbc.com/news/world-asia-india-57225922

Christiawan, R. (2020). Politik Hukum Kontemporer,Covid dan Normal baru Hukum,. Depok: Raja Grafindo Persada.

Desere, B. (2000). Theory of state paternalistic. Berlin: Blackstone Press Limited.

Indradie, A. (2020). Evaluasi Perilaku Masyarakat dalam Memerangi Covid-19. Lifestyle. Retrieved from https://lifestyle.kontan.co.id/news/evaluasi-perilaku-masyarakat-dalammemerangi-covid-19 
Majid, N. (1997). Atas Nama Beragama dan Berbangsa di masa Transisi. Jakarta: Paramadina. Panjaitan, M. J. (2020). Pola Penanganan Covid-19 dalam Perspektif Perlindungan Hak Asasi Manusia. In APPTHI.

Presiden, R. Surat Edaran (SE) Satuan Tugas Penanganan Covid-19 Nomor 13 Tahun 2021 tentang Peniadaan Mudik Hari Raya Idul Fitri Tahun 1442 Hijriah dan Upaya Pengendalian Penyebaran Covid-19 Selama Bulan Suci Ramadhan 1442 Hijriah. , Pub. L. No. 13(2021).

Rohmah, N. N. (2020). Media Sosial Sebagai Media Alternatif Manfaat dan Pemuas Kebutuhan Informasi Masa Pandemik Global Covid 19 (Kajian Analisis Teori Uses And Gratification). Al-I'lam: Jurnal Komunikasi Dan Penyiaran Islam, 4(1), 1-16. Retrieved from https://journal.ummat.ac.id/index.php/jail/article/view/2957/1905

Roy. (2020, May 22). Jokowi \& Anies Kompak Sarankan Warga Mudik Virtual , Artinya ? CNBC Indonesia. Retrieved from https://www.cnbcindonesia.com/tech/20200522095703-37160186/jokowi-anies-kompak-sarankan-warga-mudik-virtual-artinya 